\title{
INFLUENCE OF THE DEFLASKING DELAY TIME ON THE DISPLACEMENTS OF MAXILLARY DENTURE TEETH
}

\author{
INFLUÊNCIA DO TEMPO DE DEMORA PARA DESINCLUSÃO NOS \\ DESLOCAMENTOS DENTAIS EM PRÓTESE TOTAL SUPERIOR
}

\author{
Rafael Leonardo Xediek CONSANI \\ Volunteer Assistant Professor, Department of Prosthodontics, Piracicaba Dental School, State University of Campinas, São Paulo, Brazil. \\ Marcelo Ferraz MESQUITA \\ Professor, Department of Prosthodontics, Piracicaba Dental School, State University of Campinas, São Paulo, Brazil. \\ Mário Alexandre Coelho SINHORETI \\ Professor, Department of Restorative Dentistry, Piracicaba Dental School, State University of Campinas, São Paulo, Brazil. \\ Simonides CONSANI \\ Professor, Department of Restorative Dentistry, Piracicaba Dental School, State University of Campinas, São Paulo, Brazil.
}

\begin{abstract}
7 he purpose of this study was to investigate the displacement of teeth occurring in dentures following storage in water at a temperature of $37^{\circ} \mathrm{C}$. Ten maxillary dentures were constructed with Classico heat-cured acrylic resin using conventional metal flasks. Metallic reference pins were placed on the incisal border of the central incisors (I), buccal cusp of the first premolars (PM), and mesiobuccal cusp of the second molars (M). The acrylic resin was polymerized twelve hours after final flask closure in a water cycle at $74^{\circ} \mathrm{C}$ for 9 hours. The flasks were removed from the thermo-curing unit after water cooling and then bench stored for 3 hours. After deflasking and finishing, the dentures were stored in water at a temperature of $37^{\circ} \mathrm{C}$ for periods of 7,30 , and 90 days. Following deflasking and each storage period tested, the I-I (incisor to incisor), PM-PM (premolar to premolar), and M-M (molar to molar) transverse distances, and LI-LM (left incisor to left molar) and RI-RM (right incisor to right molar) anteroposterior distances were measured with a STM Olympus microscope, with accuracy of $0.0005 \mathrm{~mm}$. Colleted data were submitted to ANOVA and Tukey test (5\%). No statistically significant difference was observed in the displacement of teeth in the transverse and anteroposterior distances.
\end{abstract}

UNITERMS: Maxillary denture; Water storage; Teeth movement; Flask cooling.

\section{INTRODUCTION}

A classic early publication recognized that the dimensional increase of the acrylic resin after soaking in water is usually greater than the polymerization shrinkage ${ }^{16}$. Since base polymerization shrinkage is unavoidable, a certain lack of dimensional accuracy has been accepted as one of the disadvantages of the construction of complete dentures, which is partially compensated by water sorption ${ }^{13}$.

The undesirable warpage and distortion of the dentures base occurred during clinical service is due to dimensional changes that occur in the acrylic resin ${ }^{14}$ and may be caused by one of the following factors: sorption or loss of water from the resin base, release of stresses, and flexure fatigue of the base ${ }^{19}$.
According to the diffusion theory for assessing the quantitative aspects of the kinetics of water sorption, the diffusion coefficient governs the rate of water sorption and the time required to reach balance, which is also proportional to the specimen thickness ${ }^{11}$. This fact means that the denture should fit better after water sorption than immediately after processing, since the shape of the oral tissues remains the same $^{19}$. A study on patients supports this hypothesis. The good wetting characteristics of the denture base are important ${ }^{21}$, because materials with different surface energies have varying wettabilities?.

It has been demonstrated that water sorption by the denture during clinical use is not large, and the resultant expansion caused partially compensates the polymerization shrinkage ${ }^{8}$, where water balance and consequent dimensional 
stability of the denture base are often attained ${ }^{15}$.

A study demonstrated that the dimensional changes of light-cured, heat-cured, and self-cured denture base resins were different from each other when stored in distilled water at $37^{\circ} \mathrm{C}$ for 7 days $^{5}$. Conversely, the linear dimensional changes observed were similar in all resin brands after storage in water for 30,60 and 90 days at $37^{\circ} \mathrm{C}$, and these changes were so small that they were not clinically detectable . $^{6}$

Measurements made using the continuous injection technique after immersion in water at room temperature for 1-8 weeks demonstrated that the base dimensional change was reduced, while no influence was observed in the tooth movement for the trial-pack technique. In addition, these dimensional changes were influenced by the palatal shape ${ }^{17}$.

The water saturation of both dry heat and wet heatprocessed dentures was observed to be relatively low, due to their high initial water content. Therefore, the linear expansion associated with water sorption did not entirely compensate for the processing shrinkage of dry and wet heatprocessed dentures, and did not demonstrate statistically significant differences in the resulting shrinkage ${ }^{20}$.

The purpose of this study was to verify the effect of water sorption on the displacement of teeth in maxillary dentures following storage for 7, 30 and 90 days at a temperature of $37^{\circ} \mathrm{C}$, when the flasks were cooled in the own curing water and then bench stored for 3 hours.

\section{MATERIAL AND METHODS}

Ten maxillary dentures were constructed from similar stone casts simulating an arch without irregularities in the alveolar ridge crest. Wax denture base plates with a thickness of $2 \mathrm{~mm}$ were made on the respective casts, and the height of the occlusion wax rims was $20 \mathrm{~mm}$ in the buccal sulcus of the cast and $10 \mathrm{~mm}$ in the second molar area. The maxillary stone cast was mounted in a Mondial 4000 semi-adjustable articulator (Bio-Art Dental Products, Sao Carlos, SP, Brazil) with the wax rim interocclusal relation according to the mandibular stone cast teeth, with the following references: intercondylar distance in $\mathrm{M}$, Bennett angle at $15^{\circ}$, and condilar guide at $30^{\circ}$. In order to accurately mount all dentures on the articulator, similar V-shaped notches were carved in the base of the maxillary casts.

The arrangement of the left anterior teeth was initiated with the carved wax rim serving as a guide to the positions of the central and lateral incisors and canines. The same procedure was employed at the right side. The posterior teeth were arranged starting with the first premolar until the second molar. The same procedure was used at the right arch. The teeth arrangement for the interocclusal relationship was anterior vertical overlap and posterior in Angle class I.

Metallic reference pins were placed in the incisal border of the central incisors, buccal cusp of the first premolars, and mesiobuccal cusp of the second molars. The maxillary dentures were conventionally flasked in Herodent Soli-Rock dental stone (Vigodent, Rio de Janeiro, RJ, Brazil), using a standard metallic flask (J. Safrany Metallurgy Co., Sao Paulo, Brazil). One hour after flasking, the waxed dentures were softened for 10 minutes in boiling water. The two halves of the flasks were separated, the wax removed and the stone cleaned with liquid detergent and boiling water solution. After bench cooling, one coat of sodium alginate (Isolak; Classico Dental Products, Sao Paulo, SP, Brazil) was used as a mold separator.

The heat-cured acrylic resin (Classico Dental Products), based on polymethylmethacrylate, was prepared with a polymer: monomer ratio of 3:1 by volume, and the dough flasked in the plastic stage. A polystyrene sheet was used as a separating medium between the gypsum and the acrylic resin during the initial flask closure under a load of 850 kilograms-force (kgf). After the flask was opened, the polystyrene sheet was removed, and the acrylic resin excess trimmed. The final packing pressure was $1,250 \mathrm{kgf}$. Twelve hours after the final flask closure, the acrylic resin was polymerized in water at $74^{\circ} \mathrm{C}$ for 9 hours. The curing unit was programmed to raise the temperature to $74^{\circ} \mathrm{C}$ at 1 hour, and then maintained at $74^{\circ} \mathrm{C}$ for 8 hours. After polymerizing, the flasks were slowly cooled inside the water bath, removed from the thermo-curing unit (Termotron Dental Products, Piracicaba, SP, Brazil), and bench stored for 3 hours. After this period, the dentures were deflasked, polished, and the I-I (incisor to incisor), PM-PM (premolar to premolar), and M-M (molar to molar) transverse distances, and LI-LM (left incisor to left molar) and RI-RM (right incisor to right molar) anteroposterior distances (Figure 1) were measured with a STM microscope (Olympus Optical Co., Tokyo, Japan) with a precision of $0.0005 \mathrm{~mm}$. The dentures were then individually stored in water at $37^{\circ} \mathrm{C}$ in an Orion model 502 C stove (Famem, Sao Paulo, SP, Brazil) for periods of 7, 30 and 90 days. After each water storage periods, the dentures were removed from the water, the teeth distances were measured in the same way as performed for the deflasked period, and again stored in water according to the protocol. Collected data were submitted to ANOVA and Tukey test at significant level of $5 \%$.

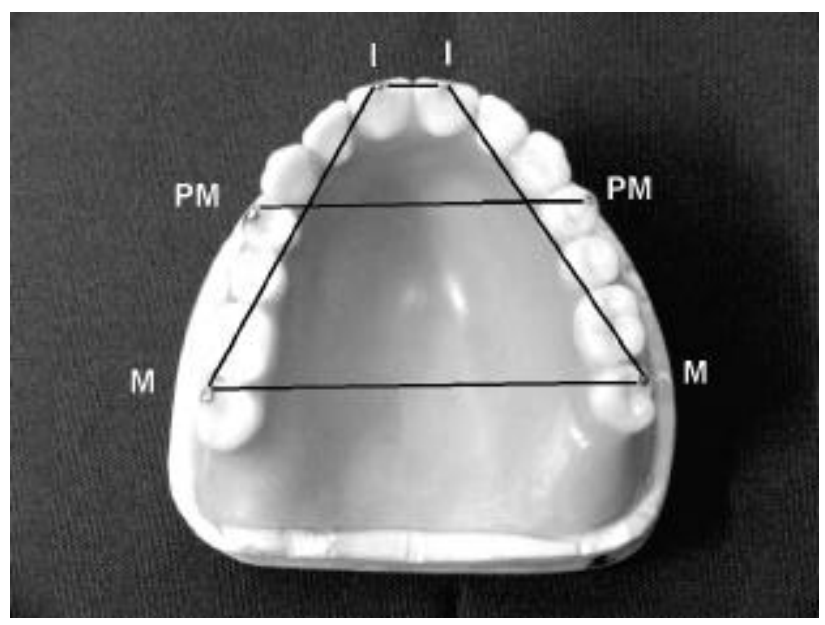

FIGURE 1- Transverse and anteroposterior teeth distances 


\section{RESULTS}

The values for the transverse and anteroposterior distances were not statistically different when the water storage periods were compared to the deflasking period, independently of the teeth distance (Table 1). No statistically significant difference was also observed in these measurements when the teeth distances were considered (Table 2).

\section{DISCUSSION}

Older and classic studies have demonstrated that the expansion of heat-cured resin bases caused by water sorption partially compensates the shrinkage occurring during denture polymerization $^{10,13}$.

The effect of water sorption on the displacement of teeth is difficult to evaluate, since several studies have presented divergent results. An earlier study developed by Mowery, et al. ${ }^{11}$, for example, demonstrated that the water sorption by the resin base occurs during clinical use and that the resulting dimensional change may affect the denture occlusion. Although the complex expansion in the horizontal and vertical planes after water sorption causes changes in the occlusion due to displacement of the teeth, the reduction of the vertical dimension is small and may cause no discomfort to the patient ${ }^{11}$.

TABLE 1- Means \pm SD of teeth movement $(\mathrm{mm})$ for the deflasking and water storage periods, regardless of the teeth distances

\begin{tabular}{lcl}
\hline Storage period & Mean & $\mathbf{5 \%}$ \\
\hline Deflasking & $34.37 \pm 13.90$ & $\mathrm{a}$ \\
1 week & $34.34 \pm 13.93$ & $\mathrm{a}$ \\
1 month & $34.30 \pm 13.99$ & $\mathrm{a}$ \\
3 months & $34.39 \pm 13.98$ & $\mathrm{a}$ \\
\hline
\end{tabular}

Means followed by identical letters do not differ statistically (5\%).
Some expansion was expected to occur when the deflasked dentures were immersed in water, since earlier studies have long established that water sorption by acrylic resin really occurs ${ }^{10,13}$. However, the results of this study showed that the water storage promoted values with no statistically significant differences when compared to the deflasking period, independently of the teeth distance factor (Table 1). These results are not consistent with a previous study that showed that the monomer remaining immediately after deflasking of the specimens affects the water uptake, and conversely no significant differences in the linear dimension of the acrylic resin specimens were found due to storage in water for up to 90 days $^{6}$. After storage in water for 30 days, the acrylic resin bases demonstrated no significant changes in the dimensional expansion ${ }^{1,3}$. Similar results were observed in this study when the transverse and anteroposterior displacement of teeth were studied in relation to all periods of water storage.

When the teeth distance factor was ignored, there was no statistical significant difference between the deflasked value and the values obtained after storage for 7, 30, 90 days, in all transverse and anteroposterior distances (Table 2 ). The water bath cooling-bench storage for 3 hours combination used in this study to cool the flasks before denture deflasking did not promote any significant effect in the displacement of teeth. This result was not consistent with an earlier study that demonstrated differences in the water uptake level according to the flask cooling method used. Greater linear changes were observed in the bench cooled processed base dentures than those cooled slowly inside the water bath ${ }^{20}$. Dimensional changes by water sorption cause expansion apparently due to the entrance of water between molecules of the polymethylmethacrylate ${ }^{2,4}$, resulting in a plasticizing effect ${ }^{12}$, when absorbed during polymerization or immersion in water ${ }^{18}$. Probably, the additional bench storage for 3 hours did not modify the dimensional conditions established by water bath cooling in relation to stress release, since the changes due to the cooling temperatures involved in this study were not significant.

This study showed similar displacement of teeth after all storage periods due to a similar amount of water uptake by volume of mass, regardless of the amount of residual monomer presents during the initial storage period. It is obvious that the high initial water content in the wet heat-

TABLE 2- Means \pm SD of teeth movement $(\mathrm{mm})$ for the deflasking and water storage periods, in relation to distance factor

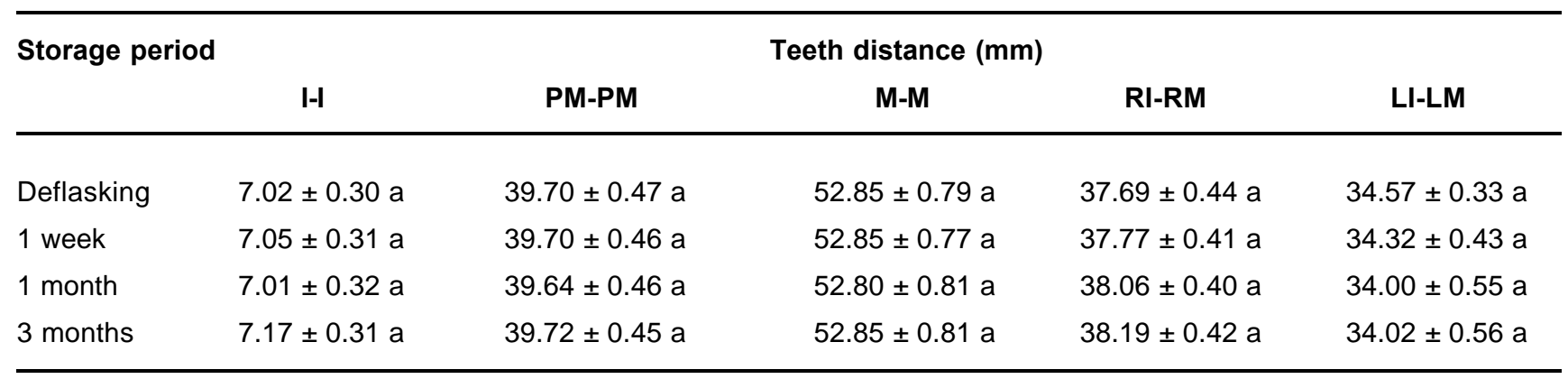

Means followed by identical letters in column do not differ statistically $(5 \%)$. 
processed dentures ${ }^{20}$ decreased the saturation level during the denture water storage in this study. This fact allowed similar stress release by denture bases, when bench stored for 3 hours, resulting in similar levels of displacement of teeth. The literature shows no significant differences in the linear dimensional change between points when the denture base was allowed to cool slowly to room temperature in the water bath ${ }^{11}$. Conversely, an earlier study demonstrated that water immersion for 8 weeks partially compensated the polymerization shrinkage, and that the consequent dimensional changes were influenced by the region of measurement?

It is obvious that, independently of the flask cooling method, the complexity of the stresses in the denture procedure involves also the proximal relationship of the posterior teeth, acting as a restrictive factor in the displacement of teeth ${ }^{8}$.

These results suggest that the displacement of teeth due to denture water sorption involves other factors occurring during the denture construction, such as base thickness, geometrical palatal form, closure flask pressure, and different stresses released in different parts of the denture.

\section{CONCLUSION}

The expansion occurred in the dentures during different periods of water uptake after flask cooling by water bathbench storage association was not sufficient to alter the distances among teeth verified in the deflasking period.

\section{RESUMO}

Este estudo avaliou a movimentação dental em prótese total sob influência da armazenagem em água à temperatura de $37^{\circ} \mathrm{C}$. Foram feitas 10 próteses totais superiores com resina acrílica termopolimerizável Clássico pelo método convencional de prensagem em muflas metálicas. Pontos referenciais metálicos foram colocados nos dentes incisivos centrais (I), pré-molares (PM) e molares (M). Doze horas após a prensagem final, a resina acrílica foi polimerizada em água aquecida a $74^{\circ} \mathrm{C}$ por 9 horas. As muflas foram removidas da polimerizadora após esfriamento da água e deixadas em bancada por 3 horas. Após esse período, as próteses foram desincluídas, acabadas e armazenadas em água à temperatura de $37^{\circ} \mathrm{C}$ pelos períodos de 7, 30 e 90 dias. A movimentação dos dentes foi verificada nos períodos após desinclusão e armazenagem em água, nas distâncias transversais I-I, PM-PM e M-M e ânteroposteriores IE-ME e ID-MD com microscópio comparador Olympus, com precisão de $0,0005 \mathrm{~mm}$. Os resultados foram submetidos à análise de variância e ao teste de Tukey (5\%). Os autores concluíram que não houve diferença estatística significativa nos valores da movimentação dos dentes nas distâncias transversais e anteroposteriores, sob influência do esfriamento da mufla na combinação água de polimerização-bancada por 3 horas, quando o período de demuflagem foi comparado com os períodos de armazenagem em água.

UNITERMOS: Prótese total superior; Armazenagem em água; Movimentação de dentes; Esfriamento da mufla.

\section{REFERENCES}

1- Anderson CG, Schulte JK, Arnold TG. Dimensional stability of injection and conventional processing of denture base acrylic resin. J Prosthet Dent 1988 Sept; 60(3): 394-8.

2- Anusavice KJ. Phillips' science of dental materials. Philadelphia: WB Saunders; 1996.

3- Arioli Fillho JN, Domitti SS, Consani S. Influência das resinas acrílicas, técnicas de polimerização e tempo de armazenagem na movimentação dental em prótese total superior. Rev Prót Clin Labor 1999; 1(4): 303-8.

4- Campbell RL. Effects of water sorption on retention of acrylic resin denture bases. J Am Dent Assoc 1956 Apr; 52: 448-54.

5- DaBreo EL, Herman P. A new method of measuring dimensional change. J Prosthet Dent 1991 May; 65(5): 718-22.

6- Dixon DL, Breeding LC, Ekstrand KG. Linear dimensional variability of three denture base resins after processing and in water storage. J Prosthet Dent 1992 Jul; 68(1): 196-200.

7- Kimpara ET, Muench A. Influência de variáveis de processamento na alteração dimensional de dentaduras de resina acrílica. Rev Pós Grad 1996; 3(2): 110-4.

8- Lechner SK, Thomas GA. Changes caused by processing complete mandibular dentures. J Prosthet Dent 1994 Dec; 72(6): 606-613.

9- Monsenego P, Baszkina A, Costa ML, Lejoyeux J. Complete denture retention. Part II: Wettability studies on various acrylic resin denture base materials. J Prosthet Dent 1989 Sept; 62(3): 308-12.

10- Mowery WE, Burns CL, Dickson G, Sweeney WT. Dimensional stability of denture base resins. J Am Dent Assoc 1958 Sept; 57(5): 345-53.

11- Ristic, B.; Carr, L. Water sorption by denture acrylic resin and consequent changes in vertical dimension. J Prosthet Dent 1987 Dec; 58(6): 689-93.

12- Sadamori S, Ishii T, Hamada T. Influence of thickness on the linear dimensional change, warpage, and water uptake of a denture base resin. Int J Prosth 1997 Jan; 10(1): 35-43.

13- Skinner EW, Cooper EM. Physical properties of denture resins: Part I. Curing shrinkage and water sorption. J Am Dent Assoc 1943 Dec; 30(6): 1845-52.

14- Stebner CM. Report: Part II. An appraisal of recent significant developments in the practice of general dentistry. J Prosthet Dent 1957 Nov; 7(6): 828-32. 
15- Sweeney WT. Acrylic resin in prosthetic dentistry. Dental Clin N Amer 1958; 2: 593-602.

16- Sweeney WT, Paffenbarger GC, Beall JR. Acrylic resins for dentures. J Am Dent Assoc 1942 Jan; 29(1): 7-22.

17- Sykora O, Sutow EJ. Posterior palatal seal adaptation: influence of processing, palate shape and immersion. J Oral Reabil 1993 Jan; 20(1): 19-31.

18- Teraoka F, Takahashi J. Controlled polymerization system for fabricating precise dentures. J Prosthet Dent 2000 May; 83 (5): 514-20.

19- Woelfel JB, Paffenbarger GC. Dimensional changes occurring in artificial dentures. Int Dent J 1969 Oct; 9(4): 451-60.

20- Wong DMS, Cheng LYY, Chow TW, Clark RKF. Effect of processing method on the dimensional accuracy and water sorption of acrylic resin dentures. J Prosthet Dent 1999 Mar; 81(3): 3004.

21- Zissis A, Yannikakis S, Jagger RG, Waters MGJ. Wettability of denture materials. Quintessence Int 2001 Nov; 31(6): 457-62.

Recebido para publicação em: 06/06/2003

Enviado para reformulações em: 13/08/2003

Pronto para publicação em: 09/09/2003

Corresponding author:

Rafael Leonardo Xediek Consani

Rua Dr. José Vizioli, 255

13400-450 - Piracicaba, SP

rconsani@merconet.com.br 